\section{Tertiary Man.}

IN Prof. Fairfield Osborn's address on "The Discovery of Tertiary Man " (NATURE, Jan. 11, p. 55), it is stated, in regard to the discoveries I have made in East Anglia, that Prof. Breuil "shifts the entire pre-Chellean and Chellean flint industries from midQuaternary down into the base of Quaternary time, namely, into the first Interglacial or Mindel-Riss stage". The first inter-glacial is, however, that of the Günz-Mindel-according to the Penckian schemeand it is to this phase-represented in East Anglia by the Cromer Forest Bed-that Breuil now relegates the Chellean industry. Prof. Osborn had no doubt in mind Breuil's recently published list of his scientific papers when writing the address referred to, as in this list the impression is given, no doubt unintentionally, that the author was the first to refer the Chellean implements to the first inter-glacial epoch. This impression is, however, incorrect, as no less than ten years ago, in 1920 , I published a note in the Geological Magazine (vol. 57, No. 671; May 1920, pp. 221-224), in which, with much detail, I set forth my views on the relationship of palæolithic man to the glacial period, and stated (p. 223) that "The Chellean implements may therefore be of Günz-Mindel inter-glacial age". When I made this announcement, to which I have adhered with ever-increasing conviction, few, if any, archæologists agreed with my opinion, and it was only after several visits of Prof. Breuil to East Anglia that he was convinced of its truth.

J. REID MOIR.

\section{Entomophagous Parasites and Phagocytes.}

IN his interesting letter in NATURE of Jan. 4 on the parasites of the pine shoot moth, Evetria buoliana Schiff, Mr. C. C. Brooks gives some figures which seem to indicate a correlation between the percentage of parasitism and the size of the emerging moths, and advances the view that the diminution in size, which he has observed in moths from areas in which the parasitism is high, is due to the fact that some of the parasitised larvæ have recovered from the parasitic attack, so that the adult is able to emerge, although it shows the effect of the feeding of the parasites in its unusually small size.

It is not uncommon to find in caterpillars or pupæ the remains of dead parasites, but so far as I have observed, this is rather rare in cases where the parasitic larvæ have reached a stage so advanced as those mentioned by Mr. Brooks. His suggestion is, therefore, a highly interesting one, and it is to be hoped that he will be able to verify it by dissections.

My object in making these comments is not, however, to discuss the hypothesis put forward by $\mathrm{Mr}$. Brooks; I simply wish to make a few remarks in regard to the view he has expressed concerning the process of recovery from parasitism, and more especially the part played by phagocytes in cases of this kind.

The evidence in favour of the views advanced by Mr. Brooks is, on the whole, very unsatisfactory. What the data actually indicate is that the part played by phagocytes in relation to insect parasites is of very little importance. Metchnikoff, the founder of the phagocytic theory of immunity, long ago pointed out in his "Lectures on the Pathology of Inflammation", that the phagocytic reaction of Arthropods is, in general, very feeble.

In his excellent work on the biology of the parasitic Diptera, J. Pantel ( $\mathrm{La}$ Cellule, 26, $1^{\text {er }}$ fasc., 1910), whose conclusions were based on the study of a large number of species, states that as a general rule the free and healthy larvæ of entomophagous insects are not attacked by phagocytes.
My own conclusions, based upon the dissection of thousands of individuals of insects belonging to practically all orders, and infested by entomophagous parasites of many groups, agree perfectly with those of Pantel. Healthy parasites, no matter in what stage of the host they are found, are practically never surrounded by phagocytes, provided they lie free within the body cavity of the host. There is no particular reason for believing that the parasite larvæ repel the phagocytes. In sections of parasitised hosts the blood cells seem to be just as numerous in the vicinity of the parasite larvæ as they are in other parts of the body. They are simply indifferent to the parasites, as they are to the organs of the host itself. On the other hand, if a parasite has an anatomical relation with the host, of such nature that destruction of tissue is produced, a considerable accumulation of phagocytes may occur around the point of the lesion. The extent to which phagocytes accumulate is variable and appears to depend in part upon the specific nature of the host, and in part upon its general condition. On the other hand, an accumulation of phagocytes does not appear to exert any effect whatever on the healthy parasites.

A brief summary of the results obtained by me up to that time was published in 1915 (Bull. Soc. Zoologique de France, 40, pp. 63-68). A detailed account is now in course of preparation.

\section{Imperial Bureau of Entomology, Farnham House Laboratory, Bucks.}

\section{Scattering of a-Particles by Light Atoms.}

In a recent discussion at the Royal Society (NATURE, vol. 123, p. 246), Sir Ernest Rutherford pointed out the great importance of the experiments on the scattering of a-particles by light atoms like those of magnesium, aluminium, helium, and hydrogen which are being carried out at the Cavendish Laboratory by himself and his co-workers Bieler, Chadwick, and others. The results of these experiments show very wide variation from the classical expression obtained on the assumption of an inverse square law, and led Rutherford and Bieler to the view that the repulsive force between positively charged particles changes into an attractive one when the distance of approach is less than $3 \times 10^{-13} \mathrm{~cm}$. Many attempts have been made to get an exact expression for this force. Bieler thought the force to be given by the law $F=\frac{Z e^{2}}{r}-\frac{\mu}{r^{4}}$, while Debye and Hardemeier took the additive term to be inversely proportional to the fifth power of the distance.

While the exact form of the law will probably take some time to discover and will probably be given by some developments in the generalised theory of relativity, it is profitable to see how far the assumptions of these additional forces can be justified from the point of view of wave mechanics. Born has given a general way of treating collision problems on wave mechanics, and Wentzel, Sommerfeld, and Mitchell have deduced, by the use of Born's method, Rutherford's classical expression for the scattering of $\alpha$-particles. I have tried to explain abnormal scattering of $a$ particles by light atoms from wave mechanics by using the law $F=\frac{Z e^{2}}{r^{2}}-\frac{\mu}{r^{n}}$. It appears that the equations can be solved by the polynomial method only when $n=3$. Using this value of $n$, I have deduced an expression for scattering which is in very good agreement with the results obtained in the Cavendish laboratory.

The assumption of the same law in Schrödinger's 